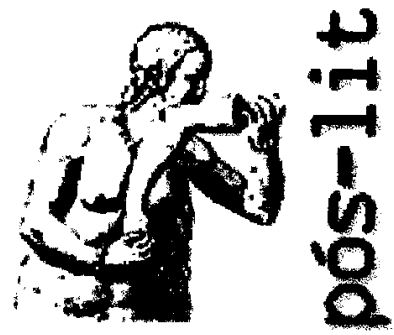

Programa de Pós-Graduação em Letras: Estudos Literários da Faculdade de Letras da UFMG

Artigo disponível em http://www.letras.ufmg.br/poslit

\section{A TENTAÇÃO DA SERPENTE}

AGOSTINHO, Cristina, BRANDÃO, Maria do Carmo, PAULA, Branca de. Luz del Fuego a bailarina do povo - uma biografia. Sõo Paulo: Circulo do Livro; Best Seller, 1994.

A estratégia desta narrativa em que várias vozes se fazem ouvir na composição funciona como eficaz e inventivo mecanismo de percussão/persuasão, ao ampliar o testemunho sobre a biografada, disseminando-o pelos contextos cultural e social que a envolvem. O prefácio do livro confirma o pacto de leitura, quando convida os leitores a "tirar sua própria conclusão" sobre a "bailarina do povo" que o livro procura retratar de forma múltipla e variada. Nesse sentido, delineiase "a tentação da serpente", a oferecer o fruto de sabores exóticos que cabe aos leitores degustar, conforme o gosto que mais lhes apetecer.

"Sedutora? Megalomaníaca? Narcisista? Histérica? Precursora do feminismo e do naturalismo no Brasil?”

Tais perguntas, lançadas no prefácio, participam da construção do texto em que se mesclam perífrases, fotos, notas ao pé de página, notícias de jornais e de revistas, recibos, fontes e obras pesquisadas, excertos de livros de Luz del Fuego, excertos da autobiografia de um de seus assassinos, ditada a um colega de prisão e a ficção da "biografia romanceada" que os reúne. Incita-se, assim, o apelo a uma leitura produtiva e em colaboração com a escrita, sem anular aquela leitura ingênua e imediata que se exime da reflexão e adentra-se prazerosamente na satisfação de encontrar no livro o hálito tagarela dos que se contentam em repetir opiniões alheias. 
O intuito maior da obra, no entanto, parece visar ao resgate de um passado que pertence às autoras - essa Luz del Fuego que fazia parte "dos assuntos proibidos de nossa infância" - e que passa também a nos pertencer, quando entramos em contato com ela, mediante os chamamentos que, nos vários capítulos do livro, provocam nossa memória. Ao colocar no palco dos debates, promovidos por tantas opiniões, a experiência incomum da figura de Luz del Fuego, a narrativa atinge o objetivo de ultrapassar os limites do mero registro dos fatos e da contextualização temporal de sua ocorrência "quase 30 anos após sua morte" -, e insere-se num espaço mais amplo e complexo: o da apreensão dos mecanismos que os engendram. A mulher Dora Vivacqua/Luz del Fuego, transitando entre a realidade e o mito, vê assim assegurada sua esfera ficcional. A "biografia romanceada" que se impôs às autoras como "forma ideal para captar a multifacetada personagem" eximiu-as de reduzir a informação, veiculada pelo relato, ao aspecto puramente documental, o que acaba por conferir à narrativa maior força questionadora no repensar a personagem juntamente com a sociedade brasileira e expôr as contradições que as percorrem.

Assumindo uma perspectiva múltipla que descarta a eleição de um significado único para a vida de Dora/ Luz, a obra propõe assegurar os pontos de convergência e de divergência entre o discurso ficcional e o documentáriobiográfico. Traz ao leitor a oportunidade de realizar uma experiência efetiva de conhecimento e de resgate da história/ vida que se pretendeu ocultar. No caso, diluindo, pela ficção, o estereótipo genérico do discurso biográfico, forma retórica que representa ou dramatiza o sujeito enquanto unidade. A obra, por sua narração, contesta seu título: a Luz del Fuego bailarina do povo não consegue obstruir a Dora Vivacqua que se abriga na "Cruz Escondida" do capítulo final.

Para o leitor, resta como uma das conclusões a tirar que, se sua leitura não resolve quais fatos textuais correspondem aos fatos da vida de Luz/Dora, permanecem nele as imagens que gostaria de reter dessa figura que demanda por tradução. E tal oportunidade lhe será possibilitada pelo acompanhamento da vida de Luz, elo partido e desmembrável, não preenchido totalmente pela narrativa e, por isso, não restrito ao passado. Como uma esfinge, Luz del Fuego, ao literalmente despir-se, conclama o povo do qual é a bailarina a decifrá-la, num desafio instigante que o remete inclusive a questionar padrōes tradicionais da família e da sociedade.

O texto literário que se constrói na e da biografia impele-a a fugir do processo linear do acúmulo quantitativo de fatos referenciais. Em troca, permite à tradição que énvolve a imagem de Luz del Fuego deixar emergir Dora Vivacqua, como possibilidade de recuperar no detalhe, no particular, a história que não pôde ser escrita, mas de cuja existência o carinho da irmã Eunice não se esquecera. Nesse trilha, procura-se avivar a voz de uma lembrança que a marginalidade imposta a Dora/Luz pela família e pela sociedade teima em apagar. No corpo-texto da narrativa, à luz de novos horizontes de expectativa e mediante o gesto estético, esculpem as autoras. Não a estátua sem data, de mármore ou bronze, conforme o desejo de Luz, mas a Luz/Dora/mito/personagem que lhes permite reconstruir a casa em ruínas da ilha do Sol e repor Eva no seu paraíso.

Ao recontar ou modificar uma história consagrada, insere-se o livro Luz del Fuego bailarina do povo uma biografia numa das mais fortes linhas do romance contemporâneo. Sua forma de contar, repleta de fatos e minguada de adjetivos, obedece aos ditames do gênero biográfico. E o seu leitor, convidado a ler a obra como ficção e biografia, pode perceber que o modo de recuperar experiências alheias e de fazê-las convergir com o vivido, ao recontá-las, estruturam o livro e revelam o seu funcionamento. 
A trança suave com que as escritoras penteiam os gêneros e as várias faces de Eva, numa tessitura delicada, expõe a transitoriedade e a fragilidade do liame que liga/desliga vida e ficção. É nesse movimento que os vários textos se entrelaçam, iluminam-se e complementam-se e permitem que a experiência única de Dora Luz seja compartilhada pela atuação do leitor, ao facultar-lhe capacidade própria de também rememorar e inventar.

Maria do Carmo Lanna Figueiredo $P U C-M G$
Programa de Pós-Graduação em Letras: Estudos Literários da Faculdade de Letras da UFMG

Artigo disponível em http://www.letras.ufmg.br/poslit 